\title{
SERVICE PERIOD AS A MODERATOR TO THE BEHAVIOUR AND WORK PERFORMANCE RELATIONSHIP IN THE ORGANISATION
}

\author{
Khatijah Othman ${ }^{1 *}$, Siti Nurbaya Ismail ${ }^{2}$, Shahrul Hafifi Mohd Fuad², \\ Masni Md Hasim², Fadhilah Othman², Muhammad Rahmat Abdullah², \\ Norwini Zaidi², Nur Adlina Addenan ${ }^{2}$, and Nik Nadian Nisa Nik Nazli ${ }^{3}$ \\ ${ }^{1}$ Faculty of Leadership and Management, Universiti Sains Islam Malaysia, \\ Bandar Baru Nilai, 71800 Nilai, Negeri Sembilan, Malaysia \\ ${ }^{2}$ Registrar Office, Universiti Sains Islam Malaysia, Bandar Baru Nilai, \\ 71800 Nilai, Negeri Sembilan, Malaysia \\ ${ }^{3}$ Business School, Universiti Kuala Lumpur, 50250, Kuala Lumpur, Malaysia \\ *Corresponding author: khatijah@usim.edu.my
}

Published online: 25 October 2019

To cite this article: Othman, K., Ismail, S.N., Mohd Fuad, S.H., Md Hasim, M., Othman, F., Abdullah, M.R., Zaidi, N., Addenan, N.A., and Nik Nazli, N.N.N. (2019). Service period as a moderator to the behaviour and work performance relationship in the organisation. Asian Academy of Management Journal, 24(Supp. 2), 51-65. https://doi.org/10.21315/aamj2019.24.s2.4

To link to this article: https://doi.org/10.21315/aamj2019.24.s2.4

\begin{abstract}
Performance and productivity are strongly influenced by the workers' behavioural attitudes. Committed employees' behaviours will produce higher performance and productivity in their work. Undeniably, the better commitment would help to reduce employees' personal problems such as differing work, absenteeism, and negligence in doing work. High performance affects employees and ensures that every task is done efficiently, and it provides employees a high level of job satisfaction. The longer the worker stays in a workplace, the higher the performance level shown towards the organisation. The objective of this study is to examine the relationship between the workers' behaviours and work performances in the organisation, and to determine the service period as a moderator in relationship between behaviour and work performance. The method used in this study is a quantitative methodology, and the survey questionnaires have been conducted on 100 respondents consisting of professional and administrative officers in an organisation. The data analysis was performed using Structural Equation Modeling
\end{abstract}

(C) Asian Academy of Management and Penerbit Universiti Sains Malaysia, 2019. This work is licensed under the terms of the Creative Commons Attribution (CC BY) (http://creativecommons. org/licenses/by/4.0/). 
(SEM) method with the help of AMOS software version 23. The finding shows that there is a positive relationship between employees' behaviour and work performance, and the duration of service moderated the relationship between behaviour and work performance. In this regard, workers who have worked a long period of service with an organisation exhibit the behaviour of commitments to work and produce more efficient and effective work performance in the organisation.

Keywords: behavioural attitude, work performance, service period, performance and productivity, Structural Equation Modeling

\section{INTRODUCTION}

There are various challenges faced by the private and public sectors in ensuring the goals of the organisation are achieved. To achieve organisational goals, the performance of public and private sector employees should be at the highest level of competence and work performance. Employees are valuable assets for an organisation in determining the organisation's success, especially in a competitive global environment. Noel (2009) defines work performance as an activity and individual productivity needs to be aligned with the goals of the organisation, whereas Spector (2003) accentuated that good work performance can increase organisational productivity and indirectly improve the country's economy. Utusan Online (2010) reported that there were a total of 6,133 problematics and low-performing civil servants. It was quite surprising since the government has implemented various transformations and reforms in the civil service. Although the problematic number is still small, the situation will affect the image of public service if not dealt with immediately. It seems that the problem of discipline, health, and low performance were the three most common problems. Such issues will affect the image of the civil service and raise questions about the performance of civil servants whether they can perform their responsibilities efficiently and efficiently while carrying out their assigned tasks. Mohd Noor (2015) reported that around 2,943 civil servants were categorised under below performance with work performance indicator scoring less than $60 \%$. They were involved in problems such as being absent from work and other disciplinary issues. This is becoming an alarming situation since it can tarnish the image of the public service in Malaysia.

By recognising the importance of work performance in enhancing excellence in organisation, this study looks at the relationship between employee behaviour and work performance among professional and administrative staff in one of the public higher learning institutions in Malaysia. Additionally, the length of service for an employee plays an important role in being a boost factor towards individual work performance. The longer an employee works, the higher the level 
of work performance as wider work experience should help improve one's work performance. In particular, the objectives of this study are as follows:

1. To examine the relationship between behaviour and work performance among professional and administration employees

2. To determine service period as a moderator in relationship between behaviour and work performance among professional and administration employees

\section{LITERATURE REVIEW}

\section{Work Performance}

Work performances among individuals in an organisation differ. This may be due to the differences in behaviours for each employee. Work performance refers to how the individual takes action and contributes to behaviour that is aligned with the organisation's objectives. The task of the worker is the responsibility of that particular individual in completing his/her job (Dessler, 2000). Employees play an important role as key assets in an organisation to achieve organisational goals. Employees with good working performance can contribute to the best of an organisation in achieving the goals set. Employees who are more satisfied with their job tend to have a stronger motivation to perform and display some positive work behaviours (Chin, 2015; Fu \& Deshpande, 2014).

\section{Behaviour}

Employee behaviour is an important element in achieving organisational goals. The effective productivity of an organisation is due to the positive behaviour of a worker. Ahmad (2007) states that the production of more productive work is influenced by the behaviour of workers who are committed to the organisation. It contributes to overall organisational performance (Tan \& Nur Riza, 2013). Specifically, when employees are more committed to their organisations, they would have greater involvement in the organisation's activities and a stronger desire to engage in beneficial in-role and extra-role behaviours ( $\mathrm{Li} \&$ Ngo, 2017).

\section{Hypotheses Development}

This study assumes that behaviour is a factor that will affect the performance of work among professional and administrative staff and service period as a moderator between behaviour and work performance relationship. 


\section{Relationship Between Behaviour and Work Performance}

Individual performance is also influenced by the ability of the employee to act. To improve work performance of an organisation, changes must take place on individual behaviour. According to Tamkin (2005), work performance theory emphasises that self-acting individuals cannot improve organisational performance, but they can be improved better by working in teamwork in the organisation. To sum, highly skilled and qualified employees are more likely to produce high performance and different outcome (Matthew, 2003). Similarly, a study by Mat Zin (1999) found that the behaviour of employees with interest in work showed a high level of performance for the organisation. Therefore, the hypothesis formed is as follows:

H1: Behaviour has positive significant relationship with work performance

\section{Service period as a moderator}

In a review of the service period literature, most studies used time on the job or work experience or job tenure to measure service period (Quinones, Ford \& Teachout, 1995). The length of service period is one of the elements that is a measure of the improvement of individual work performance. The longer the service period of an employee in the organisation, the higher the level of individual work performance. According to the self-determination theory, motivation increases in a work situation that is more self-directed and as such results in positive behavioural and attitudinal results. However, it is hard for an organisation to give self-directed work environment to inexperienced employees since there were lacking on the knowhow to relate with the work environment and sometimes unskilled with the tasks given. Thus, Barrick, Mount and Li (2013) concluded that work motivation will become positive behaviour in the organisation where employees have more work experience. It is expected that work experience that an employee holds should lead to employee seriousness in what they do, mature judgement, stability, reduce work behaviours that are negative such as absenteeism and increase performance in workplace (Uppal, Mishra \& Vohra, 2014). Study by Ramoo, Abdullah and Piaw (2013) found that work experience is one of the factors that provide good work performance. It is supported by Cvjetković, Djordjević and Ćoćkalo (2017) where they indicated that experienced workers have more extensive range of knowledge as well as delivering high-performance work organised. No doubt, experienced workers have a willingness to improve their skills and have a strong organisational culture towards the organisation. Therefore, the hypothesis formed is as follows:

$\mathrm{H} 2$ : Service period is a moderator in the relationship between behaviour and work performance 


\section{The Research Framework}

The basic research model in this study is exhibited in Figure 1.

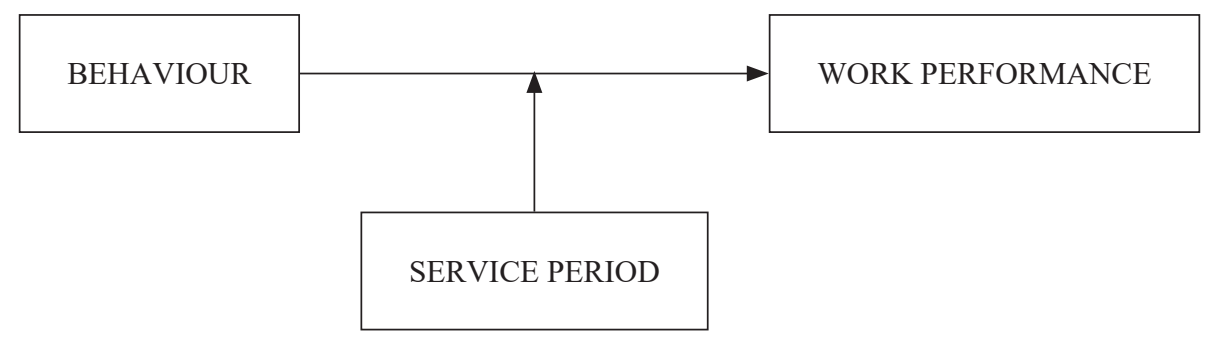

Figure 1. Conceptual framework

To meet the research objectives and based on the conceptual framework presented here, the hypotheses is constructed as follows:

H1: Behaviour has positive significant relationship with work performance

$\mathrm{H} 2$ : Service period is a moderator in the relationship between behaviour and work performance

\section{Research Methodology}

In this study, the population is the professional and administrative employees in one of the public higher learning institutions in Malaysia. This study has used simple random sampling design, and the total of 99 questionnaires were distributed among the respondents. Random sampling is the purest form of probability sampling. Each member of the population has an equal chance of being selected. This simple random sampling design has the least bias and offers the most generalisability (Sekaran \& Bougie, 2013).

\section{Data Collection Instrument}

Behaviour is referred to the questionnaire developed by Kanungo (1982) and the questions were modified by the research team after discussion. Behaviour scale consisted of 6 dimensions, i.e., about work (17 items), workplace (9 items), organisation (3 items), ethic ( 8 items), person organisation ( 3 items), and engaging work (6 items). Each item is measured using the Likert scale of 1 (Strongly Disagree) to 5 (Strongly Agree). The measurement on work performance is referred to the questionnaire developed by Goodman and Svyantek (1999) and constructed with two dimensions, i.e., individual task (9 items) and organisation 
goal (6 items). Each item is measured using the Likert 5-point scale with answers ranging from 1 (Strongly Disagree) to 5 (Strongly Agree). Convergence validity analysis was shown on all measurements, and the constructs were all found to have good convergence validity. In order to ensure individual dimensions were discriminated, this study conducted discrimination analysis, and the Kaiser Meyer Olkin (KMO) value was 0.863 . Bartlett's test of sphericity also reached statistical significance $(p<0.001)$. The tests on discrimination validity suggested that the questionnaire was fit for factor analysis. The results also suggested that the factor loadings of the dimensions were all larger than 0.68 , in line with the sample classifications of the original questionnaire and the expected results. Therefore, it was inferred that all of the dimensions had discrimination validity.

\section{Demographic profiles}

This section presents the description of the sample. The characteristics of respondents are described by gender, age, status marital, grade position, level of position, the period of service, and annual appraisal report (LPNT) in the present university. This information is presented in Table 1.

Based on Table 1, the majority of respondents are females (59.6\%), with males comprising $40.4 \%$. With regards to age, $51.5 \%$ respondents are of age $36-45$ years old, $41.4 \%$ respondents are of $26-35$ years, $6.1 \%$ are of 45 years and above, and $1.0 \%$ respondents are of age 25 and below. Majority of respondents are married (86.9\% or 86 respondents), while 13 respondents (13.1\%) are single. A number of 46 respondents $(46.5 \%)$ are of job grade 44,36 respondents $(36.4 \%)$ of grade 41,13 respondents $(13.1 \%)$ of grade 48 and 4 respondents $(4.0 \%)$ are of grade 52. Majority of respondents are permanent staff ( 77 respondents or $77.8 \%)$ and the remaining 22 respondents are contract staff $(22.22 \%)$. With regards to year of service, $53.5 \%$ of respondents have been serving for $6-10$ years, $30.3 \%$ have 11-15 years of service, $13.1 \%$ are having less than 16 years of work experience, and only $3.0 \%$ have less than 3 years of service. The majority of respondents have LPNT of (91\%-95\%), 37.4\% have $86 \%-90 \%$ LPNT, 9.1\% have $81 \%-85 \%$ LPNT and only $2.0 \%$ have $96 \%-100 \%$. It shows that none of the staff falls into the under-performing category of less than $60 \%$ LNPT score. 
Table 1

Demographic of sampling in respondents

\begin{tabular}{|c|c|c|c|}
\hline Items & Classification & Total & Percentage \\
\hline Age & $\begin{array}{l}<25 \text { years } \\
26-35 \text { years } \\
36-45 \text { years } \\
>45 \text { years }\end{array}$ & $\begin{array}{r}1 \\
41 \\
51 \\
6\end{array}$ & $\begin{array}{r}1.0 \\
41.4 \\
51.5 \\
6.1\end{array}$ \\
\hline Gender & $\begin{array}{l}\text { Male } \\
\text { Female }\end{array}$ & $\begin{array}{l}40 \\
59\end{array}$ & $\begin{array}{l}40.4 \\
59.6\end{array}$ \\
\hline Marital status & $\begin{array}{l}\text { Single } \\
\text { Married }\end{array}$ & $\begin{array}{l}13 \\
86\end{array}$ & $\begin{array}{l}13.1 \\
86.9\end{array}$ \\
\hline Job grade & $\begin{array}{l}41 \\
44 \\
48 \\
52\end{array}$ & $\begin{array}{r}36 \\
46 \\
13 \\
4\end{array}$ & $\begin{array}{r}36.4 \\
46.5 \\
13.1 \\
4.0\end{array}$ \\
\hline Level position & $\begin{array}{l}\text { Contract } \\
\text { Permanent }\end{array}$ & $\begin{array}{l}22 \\
77\end{array}$ & $\begin{array}{l}22.2 \\
77.8\end{array}$ \\
\hline Service & $\begin{array}{l}<3 \text { years } \\
6-10 \text { years } \\
11-15 \text { years } \\
<16 \text { years }\end{array}$ & $\begin{array}{r}3 \\
53 \\
30 \\
13\end{array}$ & $\begin{array}{r}3.0 \\
53.5 \\
30.3 \\
13.1\end{array}$ \\
\hline LPNT & $\begin{array}{l}81 \%-85 \% \\
86 \%-90 \% \\
91 \%-95 \% \\
96 \%-100 \%\end{array}$ & $\begin{array}{r}9 \\
37 \\
51 \\
2\end{array}$ & $\begin{array}{r}9.1 \\
37.4 \\
51.5 \\
2.0\end{array}$ \\
\hline
\end{tabular}

\section{RESULTS AND DISCUSSION}

Before modelling the structural model and executing Structural Equation Modeling (SEM), this study has been validated for all latent constructs involved in the model (Zainudin, 2015). The validation procedure is called Pooled Confirmatory Factor Analysis (Pooled-CFA). Pooled-CFA is more efficient, thorough, and can avoid the model identification problem especially if some of the constructs have less than four measuring items (Zainudin, 2015).

Figure 2 shows that the Pooled-CFA consists of two latent constructs (behaviour and performance). In the Pooled-CFA, the process of deleting item is made for every construct by selecting item having the lowest factor loading in each construct to remove. In this study, there was no item deleted because the factor 
loading is above than 0.50 (Hair et al., 2010) and the fitness of indexes are achieved ( $p$ value $=0.000, \mathrm{CFI}=0.917$ and $\mathrm{ChiSq} / \mathrm{df}=2.054)$. According to Zainudin (2015), the rule of thumb for the fitness indexes are RMSEA $<0.08$, CFI $>0.90$ and $\mathrm{ChiSq} / \mathrm{df}<3.00$.

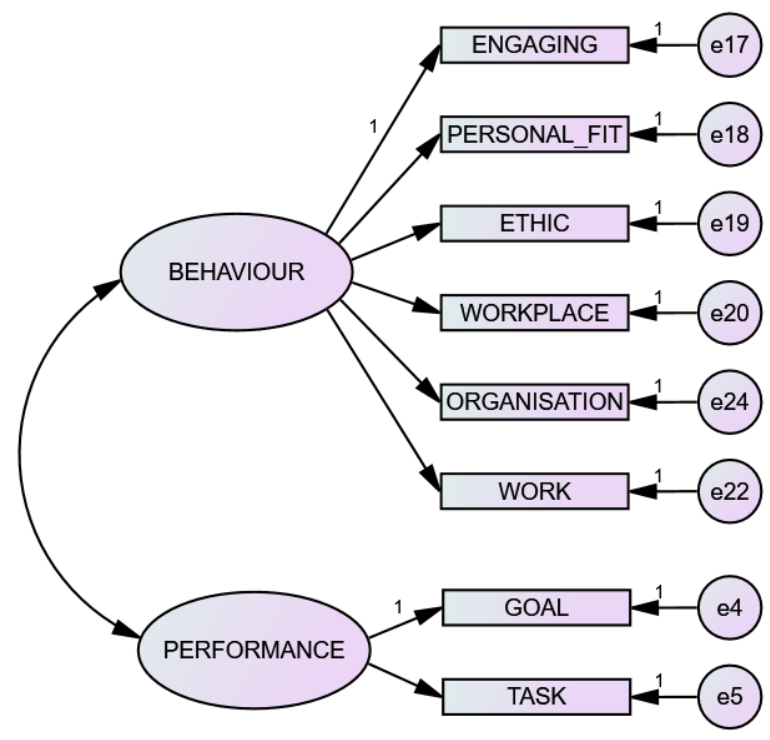

Figure 2. The pooled-CFA for all constructs in the study

Figure 3 indicates the results of the SEM Amos analysis and one hypothesis was measured. The first hypothesis, $\mathrm{H} 1$ predicts that behaviour is positively significant related to performance. Table 2 indicates that a behaviour is positively significant related to performance (CR: 6.792, $p=0.00)$. Therefore, $\mathrm{H} 1$ can be accepted.

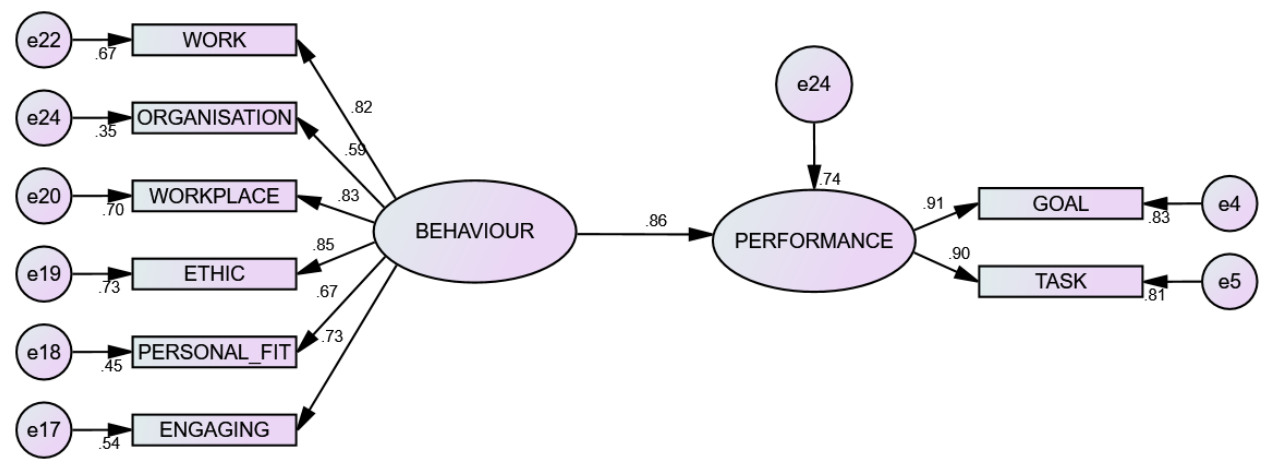

Figure 3. Structural model 
Table 2

Structural estimates of the modal

\begin{tabular}{lccccc}
\hline Path & Estimate & SE & CR & P & Result \\
\hline H1: Performance $\rightarrow$ Behaviour & 0.920 & 0.135 & 6.792 & $* * *$ & Supported \\
\hline
\end{tabular}

From the analysis, it was concluded that the hypothesis $\mathrm{H} 1$ is accepted. There is a statically significant positive relationship between behaviour and performance. According to Table 3, $\mathrm{R}^{2}$ value for the relationship between behaviour and performance is 0.736 , which explains $74 \%$ of the variability of the response data around its mean. A positive correlation is a relationship between two variables such that as the value of one increases, the other also increases. In other words, the higher level in behaviour will increase the level of work performance employees in the workplace.

Table 3

Square multiple correlation $\left(R^{2}\right)$ - Behaviour to performance

\begin{tabular}{lc}
\hline Construct & Estimate \\
\hline Performance & 0.736 \\
\hline
\end{tabular}

\section{Moderation Analysis}

According to Zainudin (2015), analysing the moderating effect for the model with latent construct is very complicated. The normal modelling procedure using interaction terms is not practical with latent constructs since it would cause problems with model convergence as well as distortion of standard errors. In the end, it resulted in model misfit and the procedure stops. The multi-group CFA has been suggested as an alternative method for assessing the effect of moderator variables. The researcher only needs to identify the path of interest where the moderator variable is to be assessed. This research adopted the moderation process for multi-group CFA by Zainudin (2015).

This particular path would be constrained with parameter $=1$ and the model is termed as the constrained model. The procedure is to estimate two models separately. One is constrained model (Figure 4) and the other one is an unconstrained model (Figure 5) for service period. 


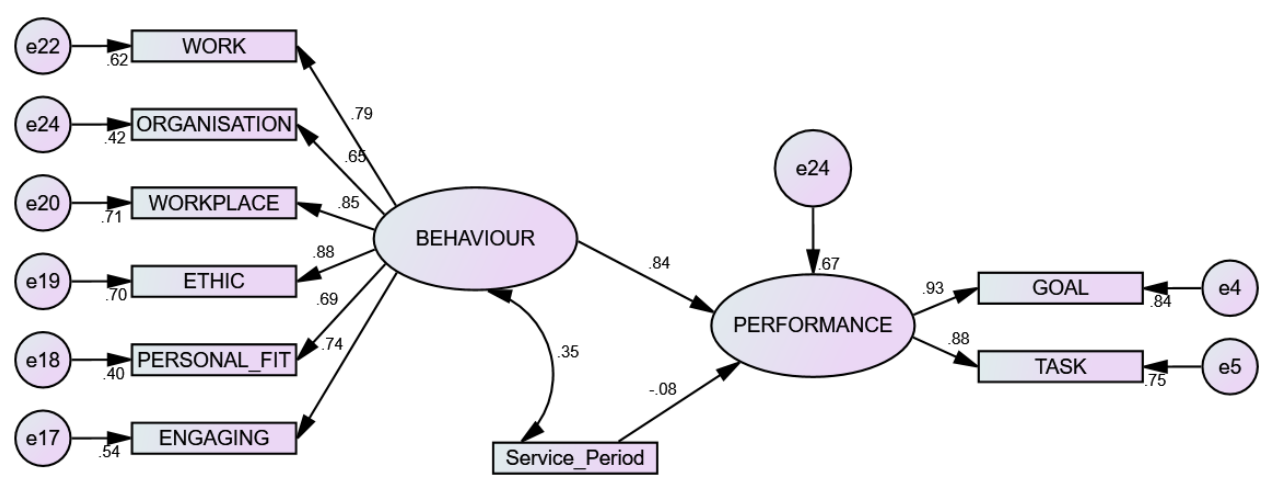

Figure 4. High data: The output of constrained model

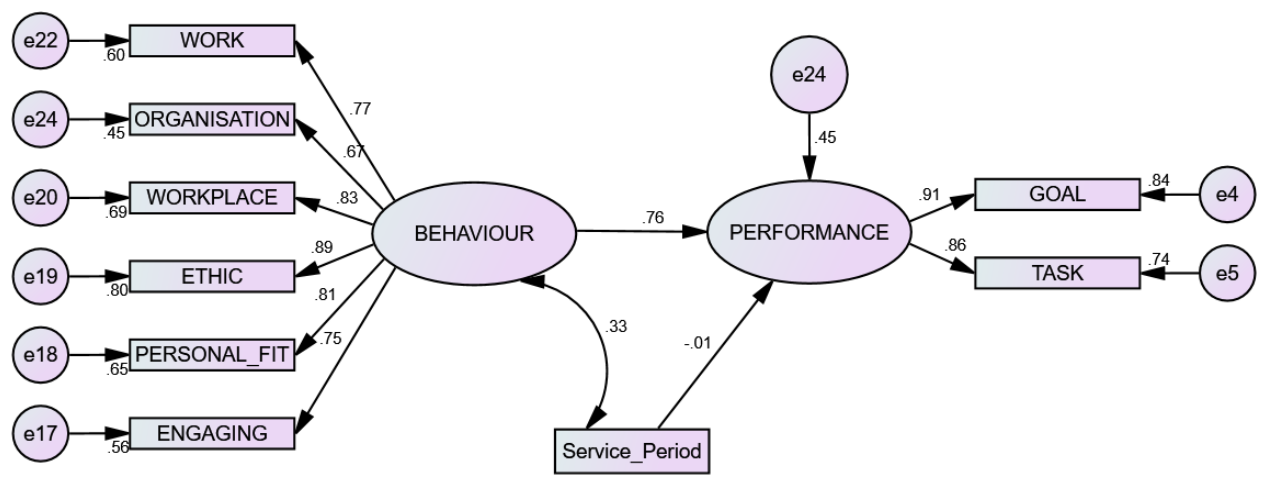

Figure 5. High data: The output of unconstrained model

Table 4 shows that the moderation test for high data education is a moderator in the relationship between behaviour and performance, and is significant since the difference in Chi-square value between the constrained and unconstrained model is 24.666 , while the Degree of Freedom is $13-12=1$ which is exceeding the requirement 3.84 (Zainuddin, 2015).

Table 4

The moderation test for high data service period

\begin{tabular}{lccccc}
\hline & $\begin{array}{c}\text { Constrained } \\
\text { model }\end{array}$ & $\begin{array}{c}\text { Unconstrained } \\
\text { model }\end{array}$ & $\begin{array}{c}\text { Chi-square } \\
\text { difference }\end{array}$ & $\begin{array}{c}\text { Result on } \\
\text { moderation }\end{array}$ & $\begin{array}{c}\text { Result high } \\
\text { data }\end{array}$ \\
\hline Chi-square & 55.226 & 50.267 & 4.959 & Significant & Supported \\
DF & 26 & 25 & 1 & & \\
\hline
\end{tabular}


For the test to be significant, the difference in Chi-square value must be higher than the value of Chi-square with 1 Degree of Freedom, which is 3.84 (Zainudin, 2015).

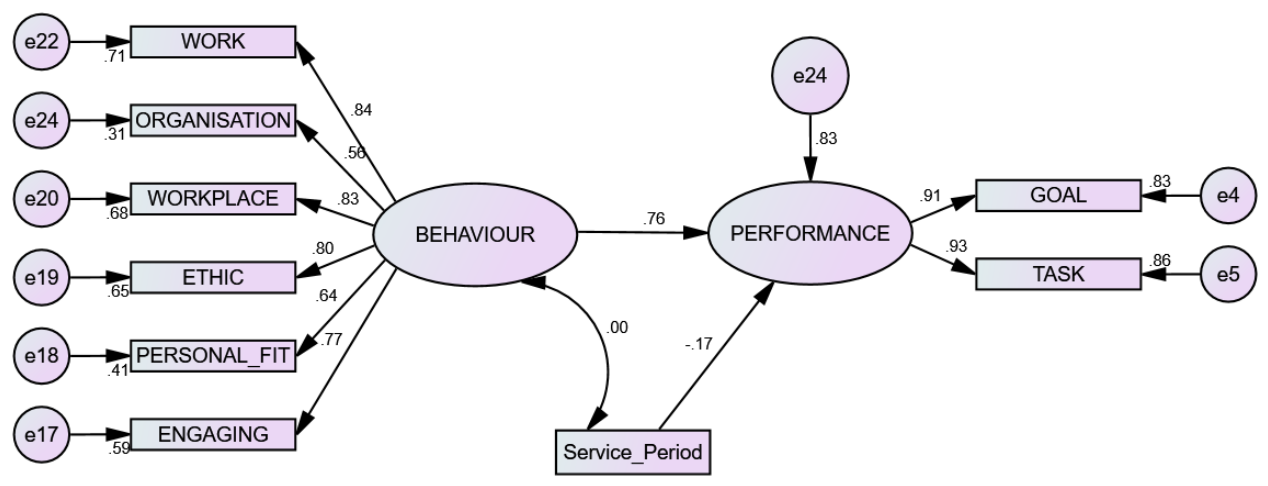

Figure 6. Low data: The output of constrained model

Figure 6 shows the constrained model for low data (service period) and the other one is an unconstrained model (Figure 7) for low data (service period).

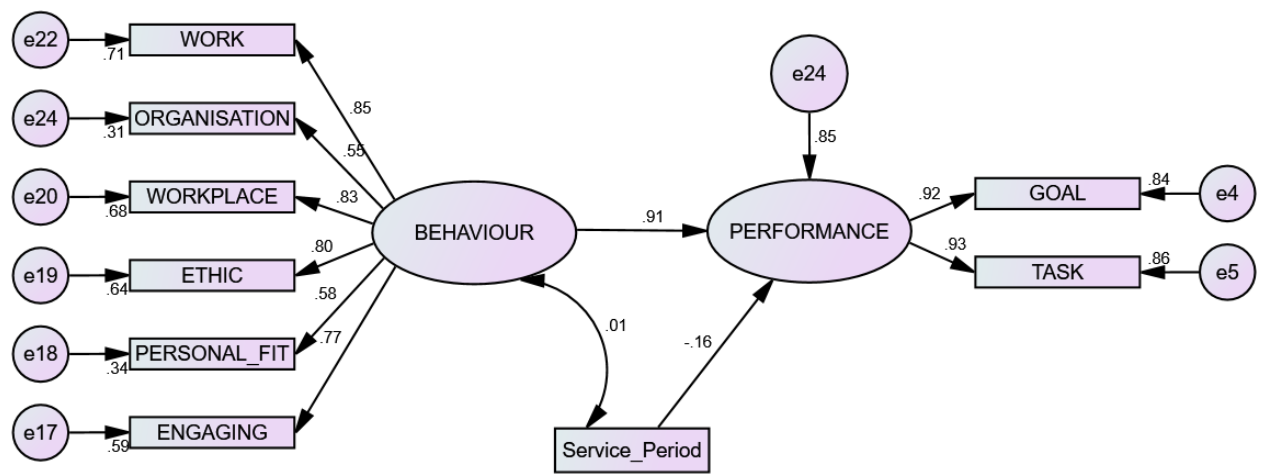

Figure 7. Low data: The output of unconstrained model

Table 5 shows that the moderation test for low data service period is significant since the difference in Chi-square value between the constrained and unconstrained model is 6.649. For the test to be significant, the difference in Chi-square value must be higher than the value of Chi-square with 1 Degree of Freedom, which is 3.84 (Zainudin, 2015). 
Table 5

The moderation test for low data service period

\begin{tabular}{lccccc}
\hline & $\begin{array}{c}\text { Constrained } \\
\text { model }\end{array}$ & $\begin{array}{c}\text { Unconstrained } \\
\text { model }\end{array}$ & $\begin{array}{c}\text { Chi-square } \\
\text { difference }\end{array}$ & $\begin{array}{c}\text { Result on } \\
\text { moderation }\end{array}$ & $\begin{array}{c}\text { Result } \\
\text { low data }\end{array}$ \\
\hline Chi-square & 62.338 & 61.509 & 0.829 & Not significant & Not supported \\
DF & 26 & 25 & 1 & & \\
\hline
\end{tabular}

From Table 4 and Table 5, the result shows that the high data service period is significant Chi-square values, while, the low data service period is not significant. Thus, the result for the type of moderation is full moderation since the standardised estimate for high service period is significant while the standardised estimate for low service period is not significant. In the analysis, it was concluded that the hypothesis $\mathrm{H} 2$ is accepted. There is a statically significant positive relationship between behaviour and performance and service period as a moderator. In this regard, employees who work for long service period in an organisation are intent to enhance performance. It is because the skills, knowledge, and behaviour gained from the work experience encourage them to expand their current skills, the beliefs of self-efficacy, and the response time when handled with work challenges, which lead to the overall enhancement of the work performance (Ahmadi et al., 2012).

\section{Findings}

In this study, it has been shown that there is a significant positive relationship between employee behaviour and attitude toward work performance, and service period is moderator. The respondents indicated that a positive employee's behaviour was directly related to improving the performance of an individual's work. A high score in the questionnaire distributed such as using skills in work (4.53), making an excellent contribution (4.44), achieving work-in-progress (4.43), attempting to solve problems (4.42), and believing that the work will succeed (4.34); all of these positive behaviours affect the commitment and good working performance. Ahmad (2007) notes that diversifying skills can make a job more productive, facilitating the implementation of work assignments, and adding new ideas. Workers influence the company's results with these positive behavioural attitudes. This attitude has been found directly and indirectly can affect employee psychology and behavioural commitment to the organisation. Therefore, the behavioural outcomes of employees should contribute to the overall performance of the organisation (Mohd Suradi et al., 2013). Khalil (2013) affirmed that performance and productivity lie in the hands of workers. Those who are committed will undoubtedly be able to show high performance and productivity. Directly, personal problems like being late work, truancy, and negligence can be 
reduced. Hussain (1991) supported that high-motivated employees allowed the organisation to increase productivity, thereby bringing renewals in the workforce and avoiding problems in work.

\section{CONCLUSION}

Overall, the findings have shown that behaviour influences individual work performance in achieving organisational goals. The length of service is a boost in the relationship between behaviour and performance. The longer individual service periods, the higher the level of work performance based on individual work experience. The findings of this study show that good employee behaviours contribute to the achievement of an excellent organisation by jointly exerting energy and creative thinking using existing organisational resources. While the individual service period is a booster factor in improving performance based on work experience itself is an asset from knowledge and expertise that can contribute to managing the organisation. At the same time, this study should be explored in greater detail so that a behavioural model of behaviour with a more robust work performance can be produced and subsequently applied in the context of a particular government organisation. Implications of this study are also discussed as a reminder and awareness to organisational management in emphasising the behaviour of individuals in the organisation in helping to improve their work performance.

\section{ACKNOWLEDGEMENTS}

This study has been conducted with the research grant provided from Universiti Sains Islam Malaysia, PPP/GPTD/30/15415 with the title Hubungan antara Sikap dengan Komitmen dan Prestasi Kerja (Kakitangan Profesional dan Pentadbiran).

\section{REFERENCES}

6,133 penjawat awam bermasalah (2010). Utusan Online. Retrieved 10 March 2018 from http://ww1.utusan.com.my/utusan/info.asp?y=2010\&dt.

Ahmadi, A.A., Jalilian, H.J., Salamzadeh, Y., Saeidpour, B., \& Daraei, M. (2012). Intellectual capital and new product development performance in production firms: A case study of Kermanshah production firms. Global Business and Management Research: An International Journal, 4(1), 15-27. 
Ahmad, N. (2007). Budaya kerja cemerlang. Kuala Lumpur: Utusan Publications \& Distributors.

Barrick, M.R., Mount, M.K., \& Li, N. (2013). The theory of purposeful work behaviour: The role of personality, higher-order goals, and job characteristics. Academy of Management Review, 38(1), 132-153. https://doi.org/10.5465/amr.2010.0479

Chin, T. (2015). Harmony and organizational citizenship behavior in Chinese organization. International Journal of Human Resource Management, 26(8), 1110-1129. https://doi.org/10.1080/09585192.2014.934882

Cvjetković, M., Djordjević, D., \& Ćoćkalo, D. (2017). Influence of knowledge and quality on business performance of companies in Serbia. Tehnički vjesnik, 24(3), 847853. https://doi.org/10.17559/TV-20160114211519

Dessler, G. (2000). Human resource management. London: Prentice Hall.

Fu, W. \& Deshpande, S.P. (2014). The impact of caring climate, job satisfaction, and organizational commitment on job performance of employees in a China's insurance company. Journal of Business Ethics, 124(2), 339-349. https://doi. org/10.1007/s10551-013-1876-y

Goodman, S.A., \& Svyantek, D.J. (1999). Person-organization fit and contextual performance: Do shared values matter. Journal of Vocational Behavior, 55(2), 254-275. https://doi.org/10.1006/jvbe.1998.1682

Hair, J.F., Black, W.C., Babin, B.J., \& Anderson, R.E. (2010). Multivariate data analysis: A global perspective (7th ed.). Boston: Pearson.

Hussain, A.A. (1991). Pengurusan organisasi. Kuala Lumpur: Utusan Publications \& Distributors.

Kanungo, R.N. (1982). Measurement of job and work involvement. Journal of Applied Psychology, 67, 341-335. https://doi.org/10.1037/0021-9010.67.3.341

Khalil, S. (2013). Sistem pengurusan tatatertib di tempat kerja. Sintok: Penerbit Universiti Utara Malaysia.

Li, H., \& Ngo, H. (2017). Chinese traditionality, job attitudes, and job performance: A study of Chinese employees. Evidence-based HRM: A Global Forum for Empirical Scholarship, 5(2), 139-150. https://doi.org/10.1108/EBHRM-08-2015-0035

Mat Zin, R. (1999). Pengurusan organisasi kerja (2nd ed.). Sintok: Penerbit Universiti Utara Malaysia.

Matthew, A. (2003). People power. Times of India, 3 February.

Mohd Suradi, N.R., Sufina R., Tarmiza M.N., Faridatulazna A.S., Zainol M., \& Choong-Y. L. (2013). Nilai-nilai dalam kepimpinan dan warga kerja universiti dan hubung kaitnya dalam mengadun prestasi organisasi. Jurnal Pengukuran Kualiti dan Analisis, 9(1), 81-94

Mohd Noor, M.H. (2015). 2943 Prestasi rendah. Harian Metro. Retrieved 10 March 2018 from https://www.hmetro.com.my

Noel, T.W. (2009). The impact of knowledge resources on new venture performance. Journal of Small Business Management, 47(1), 1-22. https://doi.org/10.1111/ j.1540-627X.2008.00259.x 
Quinones, M.A., Ford, J.K., \& Teachout, M. (1995). The relationship between work experience and job performance: A conceptual and meta-analytic review. Personnel Psychology, 6(10), 887-910. https://doi.org/10.1111/j.1744-6570.1995. tb01785.x

Ramoo, V., Abdullah, K.L., \& Piaw, C.Y. (2013). Maintaining and retaining a healthy workforce. Journal of Clinical Nursing, 22, 3141-3152. https://doi.org/10.1111/ jocn. 12260

Sekaran, U., \& Bougie, R. (2013). Research methods for business (6th ed.). Milan: Wiley.

Spector, P.E. (2003). Job satisfaction: Application, assessment, causes and consequences. Thousand Oaks, CA: Sage.

Tamkin, P. (2005). The contribution of skill to business performance report $R W 39$ department for education and skill in state for employment studies. Brighton: Institute for Employment Studies.

Tan, P.K., \& Nur Riza, M.S. (2013). The impact of complaint management and service quality on organizational image: A case study at the Malaysian public university library. AIP Conference Proceeding, 1522(1), 132-134. https://doi. org/10.1063/1.4801300

Uppal, N, Mishra, S.K., \& Vohra, N. (2014). Prior related work experience and job performance: Role of personality. International Journal of Selection and Assessment, 22(1), 39-51. https://doi.org/10.1111/ijsa.12055

Zainudin, A. (2015). Structural Equation Modeling using Amos Graphic. Shah Alam: Universiti Teknologi Mara Publication Center (UPENA). 